\title{
Effect of forage Legetan (Synedrella nodiflora) fresh and hay on the physical quality of forage pellets
}

\author{
Bambang Suwignyo ${ }^{1, *}$, Rifqi Danang Subagya ${ }^{2}$, Andriyani Astuti ${ }^{1}$, Nafiatul Umami $^{1}$ and \\ Ali Agus ${ }^{1}$ \\ ${ }^{1}$ Lecturer and researcher, Faculty of Animal Science, Universitas Gadjah Mada, Jl. Fauna No.03, \\ Karang Gayam, Caturtunggal, Kec. Depok, Kabupaten Sleman, Daerah Istimewa Yogyakarta, 55281, \\ Indonesia \\ ${ }^{2}$ Undergraduate student at Faculty of Animal Science, Universitas Gadjah Mada, Jl. Fauna No.03, \\ Karang Gayam, Caturtunggal, Kec. Depok, Kabupaten Sleman, Daerah Istimewa Yogyakarta, 55281, \\ Indonesia
}

\begin{abstract}
This study aimed to determine the effect of raw materials Legetan in the form of fresh and hay on the physical quality of pellets. Legetan (Synedrella nodiflora) was used as main ingredient, in the form of fresh and hay. The research method used a Randomized Completely Block Design (RCBD). Then, if there was a significant difference, it will be analyzed further using Duncan multiple range test (DMRT). The treatments consisted of $\mathrm{P} 1=10 \%$ rice bran $+90 \%$ fresh Legetan; $\mathrm{P} 2=$ $20 \%$ rice bran $+80 \%$ fresh Legetan; P3 $=10 \%$ rice bran $+90 \%$ hay Legetan; $\mathrm{P} 4=20 \%$ rice bran $+80 \%$ hay Legetan. The variables measured were rendement, color, texture, and price. The results showed that the utilization of Legetan forage as raw material, both hay and fresh with the proportions of rice bran either 10:90 or 20:80, had no significant effect on the physical quality of Legetan forage pellets. However, the higher the portions of Legetan forage in the forage pellets, the more affordable the pellet price will be.
\end{abstract}

\section{Introduction}

Feed plays an important role for livestock, namely for the maintenance of basic life, production, activity and health [1]. The availability of forage feed during the dry season is an obstacle at this time. In contrast, during the rainy season, forage feed is produced in abundance. Therefore, it is necessary to find alternative ways to preserve feed other than silage or fermentation [2]. One of the processing feed is in the form of pellets. Pellet is a modification of feed from the form of mash produced by pressing the pellet machine so that it becomes harder [3]. Making pellets can be done by processing of forage feed that is available and abundant around.

\footnotetext{
* Corresponding author: bsuwignyo@ugm.ac.id
} 
Legetan (Synedrella nodiflora) is often found wild in open locations, such as in pasture land, fields and gardens, and is more defined as a weed or nuisance plant. This forage bush with the local name Legetan, has a high crude fiber of $23.27 \%$ so it is very good if given to livestock. Legetan in addition to having high fiber, this plant also has a high crude protein of $20.11 \%$ so it is suitable as feed for ruminants. In addition, the nutritional content in Legetan is DM $92.87 \%$, OM $76.79 \%$, EE $7.40 \%$ and NFE 36.01\%. Indonesia with a tropical climate is very suitable as a place for this forage to grow, so it is easy to be found [4]. The protein content in fresh Legetan is at least $16.51 \%$. Carbohydrate content is $10.01 \%$ and fat is $0.25 \%$. The copper content is $1500 \mathrm{mg} / \mathrm{kg}$, lead is $600 \mathrm{mg} / \mathrm{kg}$ and hydrogen cyanide is $111.38 \mathrm{mg} / \mathrm{kg}$ [5].

Forage pellet manufacture usually uses raw materials in dry form, but by utilizing abundant local resources, forage pellets possible to be made with fresh ingredients or hay. Hay is one of the forages preserved by reducing its water content [1].

The application of forage feed technology in the form of pellets by utilizing local resources such as Legetan and natural adhesives in the form of rice bran needs to be studied further. As well as by making pellets from Legetan, it is expected to get information the quality of each different proportion by observing the physical properties of the pellet.

\section{Materials and methods}

This research was carried out at the Forage and Pasture Laboratory, Faculty of Animal Science, Universitas Gadjah Mada, Yogyakarta. This study used a manual method in the process of cutting (harvesting forage) and mixing, but the process of making pellets was with a pelletized machine. Proximate test equipment, grinder for chopping Legetan, wiley mill, and digital scales with a capacity of $5 \mathrm{~kg}$ (accuracy of $0.05 \mathrm{~kg}$ ) for weighing feed ingredients. The materials used in this study were forage Legetan weed, rice bran which functions as an additional nutrient as well as a binder and water.

Legetan forage is divided into two types of ingredients, namely dry forage/hay and fresh forage. After all the materials were available and ready, the ingredients are chopped and then mixed with other ingredients such as binders according to the treatment. The results of mixing forage and binder were put into the pelletizing machine to be compacted, after the milling process was complete, the drying process was carried out using the drying oven. Comparison between forage pellets with different portion of rice bran and Legetan forage (fresh and hay) in this study is presented in Table 1.

Table 1. Ration formulation of forage pellets was used in this research

\begin{tabular}{|l|c|c|c|c|}
\hline \multirow{2}{*}{ Feed ingredients } & \multicolumn{4}{|c|}{ Treatments } \\
\cline { 2 - 5 } & $\begin{array}{c}\text { Fresh } \\
\text { P1 }\end{array}$ & $\begin{array}{c}\text { Fresh } \\
\text { P2 }\end{array}$ & $\begin{array}{c}\text { hay } \\
\text { P3 }\end{array}$ & $\begin{array}{c}\text { hay } \\
\text { P4 }\end{array}$ \\
\hline Rice bran & 10 & 20 & 10 & 20 \\
\hline Synedrellla nodiflora & 90 & 80 & 90 & 80 \\
\hline Total & 100 & 100 & 100 & 100 \\
\hline
\end{tabular}

The parameters observed in this study were physical (rendement, color, texture) and pellet price. The data obtained were analyzed by ANOVA based on Randomized Completely Block Design (RCBD). Then, if there was a significant difference, it will be 
analyzed further using Duncan multiple range test (DMRT) with the help of the Statistical Package for the Social Science (SPSS) series 25 computer software.

\section{Results and discussion}

\subsection{Rendement}

Data on the yield value of forage pellets Legetan with different compositions and raw materials can be seen in Table 2 .

Table 2. Rendement value of Legetan pellets with different formulation and raw materials (\%)

\begin{tabular}{|l|c|c|c|}
\hline \multirow{2}{*}{ Block } & \multicolumn{2}{|c|}{ Rice Bran } & \multirow{2}{*}{ Block Average } \\
\hline Fresh & 23,13 & 23,91 & $23,52^{\mathrm{a}}$ \\
\hline Hay & 82,06 & 85,74 & $83,90^{\mathrm{b}}$ \\
\hline Average $^{\mathrm{ns}}$ & $52,59 \pm 34,03$ & $54,83 \pm 35,70$ & \\
\hline
\end{tabular}

ab Different superscripts in the same column showed a significant difference $(\mathrm{P}<0.05)$ ns non significant

$$
\begin{aligned}
& \mathrm{K} 1=\text { pellet composition } 1(90 \% \text { Legetan and } 10 \% \text { rice bran }) \\
& \mathrm{K} 2=\text { pellet composition } 2(80 \% \text { Legetan and } 20 \% \text { rice bran })
\end{aligned}
$$

The results of the analysis of variance showed that different compositions did not have a significant effect on the yield value of forage pellets. The addition of the amount of rice bran and forage did not affect the number of pellets formed after all the ingredients were mixed. In Table 2, it can be seen that there was a significant difference $(\mathrm{P}<0.05)$ from the ingredients of forage pellets to the pellet yield value. This was because the pellets used in fresh still contain a lot of water content, so hat during the pelletizing process, some of the water was wasted (as in squeezing). The water content in the raw material affects the yield number [6]. The greater the yield produced, the more efficient the treatment applied without overriding other properties [7].

\subsection{Color of pellet}

In this study, it was found that the color of the pellets at P1 (the amount of fresh forage was more than the rice bran) was greener (Figure 1) than in P2 (Figure 2). At P3 and P4 (fresh forage was replaced with hay) the color of the pellets was more brown than at P1 and P2, but at P3 it was more brown (Figure 3) than P4. At P4 the color of the pellet was more of a cream color (Figure 4). Retnani et al.[3] states that the raw materials in the mixture for pellets affects the color of the pellets. Hidayah et al. [8] states that a good product color is a color that is not much different from the original material, the darker or brwon-black the color, the lower the quality of the pellet. 


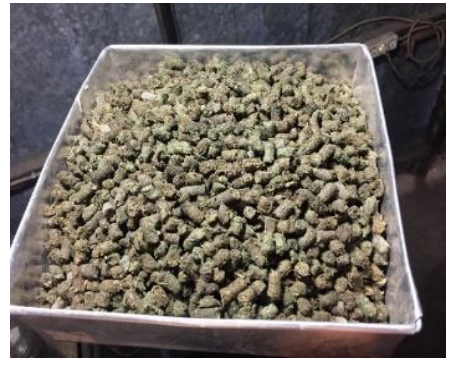

Fig. 1. Treatment P1 (10:90) fresh

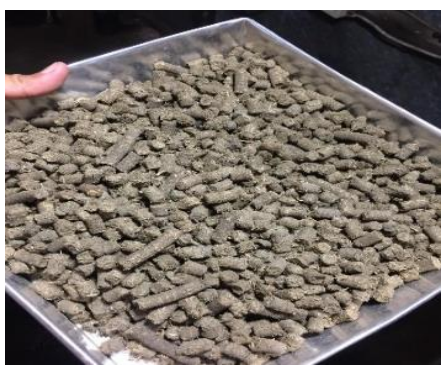

Fig. 3. Treatment P3 (10:90) hay

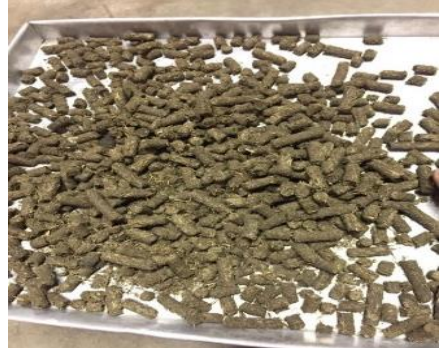

Fig. 2. Treatment P2 (20:80) fresh

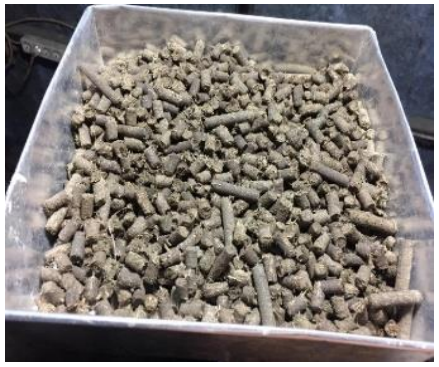

Fig. 4. Treatment P4 (20:80) hay

\subsection{Pellet Texture}

The texture of the pellets produced in this study was different, in P1 it was coarser and less solid, while P2 the pellets produced were slightly coarse and dense. At P3 and P4 the pellets were smoother, denser and solid. Based on all these treatments, the most refined, dense and solid treatment was P4. Ismi et al. [9] stated that the texture of the pellets is influenced by the constituent materials, especially the crude fiber content and the addition of the adhesive used. Widiastuti [10] added that the quality of the texture is influenced by the water content and crude fiber in the feed, feed that contains high crude fiber will make the texture coarse.

\subsection{Pellet Price}

The price of pellets is one of the considerations that need to be considered. Affordable pellet prices will attract more consumers' attention so as to increase their selling power without ignoring the nutrient content. The price of rice bran feed ingredients is approximately IDR 4,000/kg while for Legetan IDR 2,000/kg.

Based on this price, the price of forage pellets with different compositions (not including processing costs) was IDR $1,300 / \mathrm{kg}$ (composition of rice bran: Legetan was 10:90), and Rp. 2,400/kg (composition of rice bran: Legetan was 20.:80). This shows that the higher the rice bran composition in the pellet composition, the higher the pellet price produced, and vice versa.

\section{Conclusions}

Forage pellets made from Legetan with the first composition of $90 \%$ forage and $10 \%$ rice bran and the second composition with a ratio of $80 \%$ forage and $20 \%$ rice bran showed no significant difference in physical quality. The price of Legetan forage pellets will be more affordable if the amount of forage increases. 


\section{References}

1. H. R. Kartadisastra (1997)

2. I. Susilawati, J. Ilmu Ternak Univ. Padjadjaran, 12 (2012)

3. Y. Retnani, N. Hasanah, R. Rahmayeni, and L. Herawati, J. Agripet, 10, 13-18 (2010)

4. B. Suwignyo. 2020. Gulma Sebagai Pakan Ternak (Weed for Feed), Yogyakarta: K. Media (2020)

5. C. V Nnamani, United Nations University Institute for Natural Resources in Africa (2014)

6. D. A. Ertanto, S. B. Daulay, and A. P. Munir, 5 (3), 565-570, (2017)

7. W. F. Dewatisari, L. Rumiyanti, and I. Rakhmawati, J. Penelit. Pertan. Terap., 17 (2), 197-202 (2017)

8. N. Hidayah, I. P. Retno, I. M. T. Baginda, Bul. Sint.,21 (2), 21-25 (2017)

9. R. S. Ismi, R. I. Pujaningsih, and S. Sumarsih, Fakultas Peternakan Dan Pertanian Undip (2017)

10. R. Widiastuti, Doctoral Diss. Tesis, Univ. Diponegoro, Semarang (2013) 